from two to forty-three pages. The first few essays deal with the notion of fideism and with the problem of faith and knowledge, the latter being central to neoThomism-as well as to a Marxism-Leninism which refuses to see it as central to itself.

Dahm then gives a careful analysis of the elements of the dialectic that are said to be scientific in Marxism-Leninism but which he considers to be at least a priori if not fideistic. He uses long quotations from G. A. Svechnikov and others in the discussion of "Law, Order, and Principles" (pp. 21-28), "Work and Humanization" (pp. 29-34), and "Causes and Causality" (pp. 35-47). The subsequent two sections deal with problems arising out of science: "Quantum Mechanics and Information-Theoretical Probability" (pp. 48-69) and "Neurophysiology and Cybernetics" (pp. 70-72). The last four sections (or essays) take up the often discussed problems of subjective and objective, real contradictions, abstraction and the epistemological function of practice, and the nonviability of the famous "negation of the negation."

Professor Dahm's treatment of his subject matter is original in at least two respects. First, he confronts Marxist-Leninist philosophy on the battlefield of ontology, whereas most other critics are satisfied to remain on the relatively tranquil plane of epistemology and logic. Second, he uses a philosophy that is a complete system (i.e., Thomism) to oblige Marxism-Leninism to confront basic philosophic issues all along the line and not just on particular points. It is a refreshing, if inconclusive, experiment.

Almost incidentally the book serves to introduce the reader to the people and topics that are important in contemporary Soviet philosophy: again, no mean feat in such a limited space.

Thomas J. Blakeley

Boston College

\title{
SOVIET POLITICAL SCHOOLS: THE COMMUNIST PARTY ADULT INSTRUCTION SYSTEM. By Ellen Propper Mickiewicz. Yale Russian and East European Studies, 3. New Haven and London: Yale University Press, 1967. ix, 190 pp. $\$ 6.50$.
}

Mass political indoctrination, so common in Communist China today, was also a feature of the Khrushchev era in the USSR. In the words of the author, "In September 1964, just one month before Khrushchev fell from power, the system of adult education encompassed some $36,000,000$ people, of whom more than $25,000,000$, or at least 78 per cent, did not belong to the party" (p. 10). The study by Ellen Propper Mickiewicz is essentially a description and analysis of adult education under Khrushchev. The author discusses the Evening University of Marxism-Leninism, the politshkola, and the circle and independent study as ways and means in which adult education is carried on. Of these, independent study is, paradoxically, highly organized and the most advanced form of adult instruction. It may serve purposes other than education. As the author notes in describing a theoretical seminar meeting: "By requiring actors, musicians, scientists to report on principles of the political doctrine as it relates to their own work, the leader of the seminar can ascertain where each person stands" (p. 140).

The collective leadership which ousted Khrushchev also got rid of many programs he had instituted. As a result, mass political propaganda lost its previous priority, and political education reverted to its earlier elitist tradition of training 
the party membership primarily. It is on this score that the discussion falls short of being complete. Party schools and education are dealt with only in passing. Another point of criticism could be the lack of historical perspective, again because of the very brief description of what took place in political education before Khrushchev arrived on the scene. But obviously the author had to set the limits of her study somewhere, and within these limits the book provides the reader not only with novel information on the subject but also with a well-structured and analytical approach to the problem of political communications in the Soviet system.

JAAn PEnNar

Institute for the Study of the USSR

SOCIAL CHANGE IN SOVIET RUSSIA. By Alex Inkeles. Russian Research Center Studies, 57. Cambridge: Harvard University Press, 1968. xviii, 477 pp. $\$ 12.50$.

The richness and variety of Inkeles's ideas are presented in this collection of his major essays on the Soviet Union. Many of the twenty-one selections are by now classics of sociological literature and have established Inkeles as one of the major figures not only in Sovietology but also in sociology. According to Theodore Abel, distinguished teacher of Inkeles, the work of all masters of sociological craft has three common qualities: concern for the well-being of mankind, insight into the social structure of societies, and an attempt to understand the broader social changes affecting the world. By this definition Inkeles can be said to have achieved the status of one of the masters of sociology. His work has always been imbued with a humanitarian spirit and has shown concern for consolidating and increasing human freedom throughout the world. The present volume reflects this orientation beginning with the dedication and the first essay on "Social Change in Soviet Russia," and continuing through the last presentation entitled "Models and Issues in the Analysis of Soviet Society." Some sociologists think that Inkeles's knowledge and, therefore, fear of European totalitarianism has caused him to be too optimistic about the nature and future of American society. No one, however, questions the sincerity of his views.

Inkeles's most lasting contribution to sociology are the articles on the nature of social structure. These are "Social Stratification and Mobility in the Soviet Union" (1950), "National Comparisons of Occupational Prestige" (with Peter H. Rossi, 1956), "Multidimensional Ratings of Occupations" (with Peter H. Rossi and assisted by Robert Feldmesser, 1957), "Critical Letters to the Soviet Press" (with H. Kent Geiger, 1953), "Modal Personality and Adjustment to the Soviet Sociopolitical System" (with Eugenia Hanfmann and Helen Beier, 1958), "Social Stratification in the Modernization of Russia" (1960), and "Developments in Soviet Mass Communications" (revised, 1967). Probably his greatest insight into the nature of modern social organization is represented in the essay "The Totalitarian Mystique: Some Impressions of the Dynamics of Totalitarian Society," published as early as 1953. In this work Inkeles skillfully employs Max Weber's ideas on charismatic leadership in the analysis of Stalinist and Hitlerite totalitarian societies. Under his pen the concept is further illumined and refined. A charismatic leader is seen as one who is openly contemptuous of power for its own sake; he is one who seeks power for the sake of "his compulsion to make man and social development conform to the dictates of his particular perception of higher law. . . The 